DOI: 10.17707/AgricultForest.61.2.02

\author{
Gordan S. KARAMAN ${ }^{1}$
}

\title{
ON TWO SPECIES OF THE SUBGENUS NIPHARGUS \\ (ORNIPHARGUS) S. Kar. 1950 (FAM. NIPHARGIDAE) \\ FROM MONTENEGRO AND ITALY \\ (CONTRIBUTION TO THE KNOWLEDGE OF THE AMPHIPODA 280)
}

\begin{abstract}
SUMMARY
Two members of the genus Niphargus Schiődte, 1849 (subgenus Orniphargus S. Karaman, 1950, fam. Niphargidae) are studied and figured. The species Niphargus polymorphus Fišer, Trontelj \& Sket, 2006 is discovered at the first time in Montenegro (Zavrh, Nikšić) and partially described and figured.

The new subspecies Niphargus poianoi salernianus, ssp. n. is described and figured from Campania in southern Italy (S. Angelo a Fasanella, Salerno). The taxonomic status and relation of these taxa regarding other members of the subgenus Orniphargus are discussed.
\end{abstract}

Keywords: taxonomy, Amphipoda, Niphargidae, Niphargus, Montenegro, Italy, new taxon

\section{INTRODUCTION}

Recent intensive studies of the subterranean fauna over Europe, and especially of its southern part, carried out to discovery of numerous species and subspecies of Amphipoda (Crustacea Malacostraca) in the various subterranean habitats, among them new taxa also. In the subterranean waters of Europe the most numerous members of amphipods belong to the family Niphargidae (Amphipoda Gammaridea) with over 300 known taxa, and recent studies and description of various new taxa realized by various scientists are in the process.

During my numerous visits to the Museum of Natural History in Verona, I was able to study a rich collection of Niphargidae. Among other taxa of this family, I studied the samples of genus Niphargus Schiödte, 1849, from southern Italy, presented in this work.

On the other hands, I obtained one sample of genus Niphargus collected from the well in Zavrh near Nikšić (Montenegro) by Prof. Dr Vladimir Pešić from the University of Podgorica, studied and presented in this work.

\section{MATERIAL AND METHODS}

The samples of Niphargus have been preserved in $70 \%$ ethanol. The specimens were examined and dissected in the mixture of glycerine and water, using a Wild M 20 stereomicroscope and drawn using the camera lucida

\footnotetext{
${ }^{1}$ Gordan S. KARAMAN (corresponding author: karaman@t-com.me), Montenegrin Academy of Sciences and Arts, Podgorica, Montenegro.

Notes: The authors declare that they have no conflicts of interest. Authorship Form signed online.
} 
attachment. Later the dissected specimens have been transferred on slides in Liquid of Faure for final preservation. The advantage of Faure liquid is because it is possible always again dissolve the Faure liquid on slides using normal water, and move the dissected pieces again for further studies.

The body length of examined specimens was measured by tracing individual's mid-trunk lengths (tip of the rostrum to end of telson). Drawings were made using a camera lucida and inked manually.

Some morphological terminology and setae formulae follow G. Karaman's terminology (Karaman, G., 1969; 1970, 1993; 2012) for the last mandibular palpus $[\mathrm{A}=$ setae on outer face; $\mathrm{B}=$ setae on inner face; $\mathrm{C}=$ additional setae on outer face; $\mathrm{D}=$ lateral marginal setae; $\mathrm{E}=$ distal long setae] and for propodus of gnathopods 1 and 2 [ $S=$ corner spine; $L=$ lateral slender serrate spines; $M=$ facial setae; $\mathrm{R}=$ subcorner spine on inner face]. Terms "setae" and "spines" are used based on its shape, not origin.

\section{TAXONOMICAL PART}

NIPHARGUS POLYMORPHUS Fišer, Trontelj \& Sket, 2006

Figures 1-3

Niphargus polymorphus Fišer, Trontelj \& Sket, 2006: 2294, figs. 7, 20-23; G. Karaman, 2010: 23.

MATERIAL EXAMINED: Montenegro: Nikšić, Zavrh, well, 16.5.1999, 1 exp. (leg. V. Pešić).

REMARKS. The species Niphargus polymorphus has been described by Fišer et al. (2006) from Bosnia and Herzegovina (Bileća) based on female of $16.1 \mathrm{~mm}$ (holotype) and 4 females paratypes (not dissected), known from this locality only. The finding of this species in Zavrh near Nikšić extend known distribution of this species to Montenegro.

The single collected specimen of this species from Zavrh near Nikšić (Montenegro) agree mainly with the specimens from Bosnia and Herzegovina, but with some small differences. We presented a short characteristics and figures of specimen from Nikšić to put more light on the variability of the taxonomic characteristics of $N$. polymorphus, species very similar to Niphargus carcerarius G. Karaman, 1988a, known from cave-spring in Đurđevića Tara (N. Montenegro).

SHORT DESCRIPTION. Female $19.5 \mathrm{~mm}$ with setose oostegites: Head with short rostrum and short subrounded lateral cephalic lobes, eyes absent. Body strong, mesosomal segments smooth; metasomal segments 13 with dorsoposterior marginal row of short spines mixed with single short setae. 


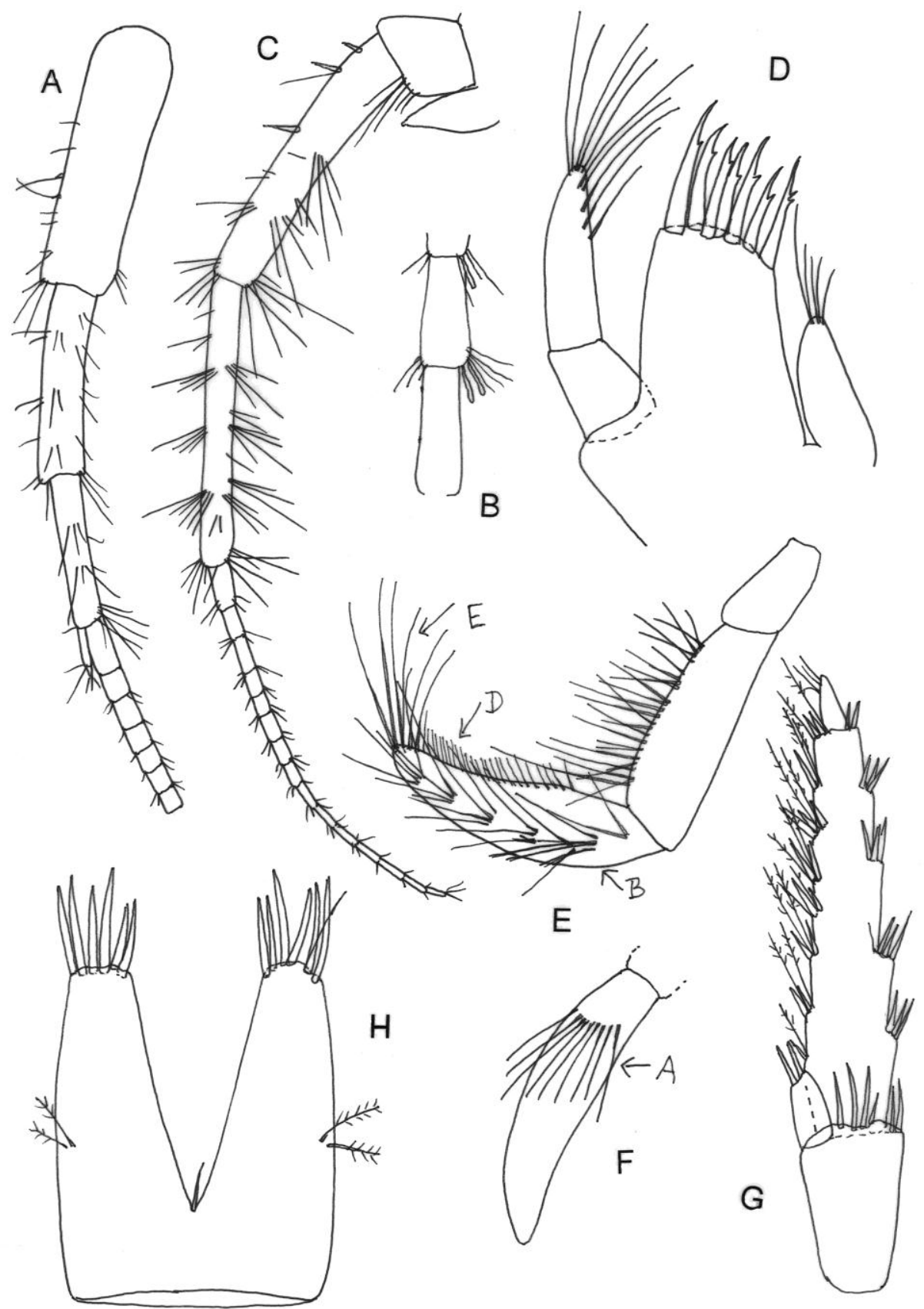

Fig. 1. Niphargus polymorphus Fišer, Trontelj \& Sket, 2006, Nikšić, Zavrh, female 19.6 $\mathrm{mm}: \mathrm{A}=$ antenna $1 ; \mathrm{B}=$ single articles of antenna 1 main flagellum; $\mathrm{C}=$ antenna $2 ; \mathrm{D}=$ maxilla $1 ; \mathrm{E}=$ mandible palpus, inner face; $\mathrm{F}=$ distal article of mandible palpus, outer face; $\mathrm{G}=\operatorname{uropod} 3 ; \mathrm{H}=$ telson. 

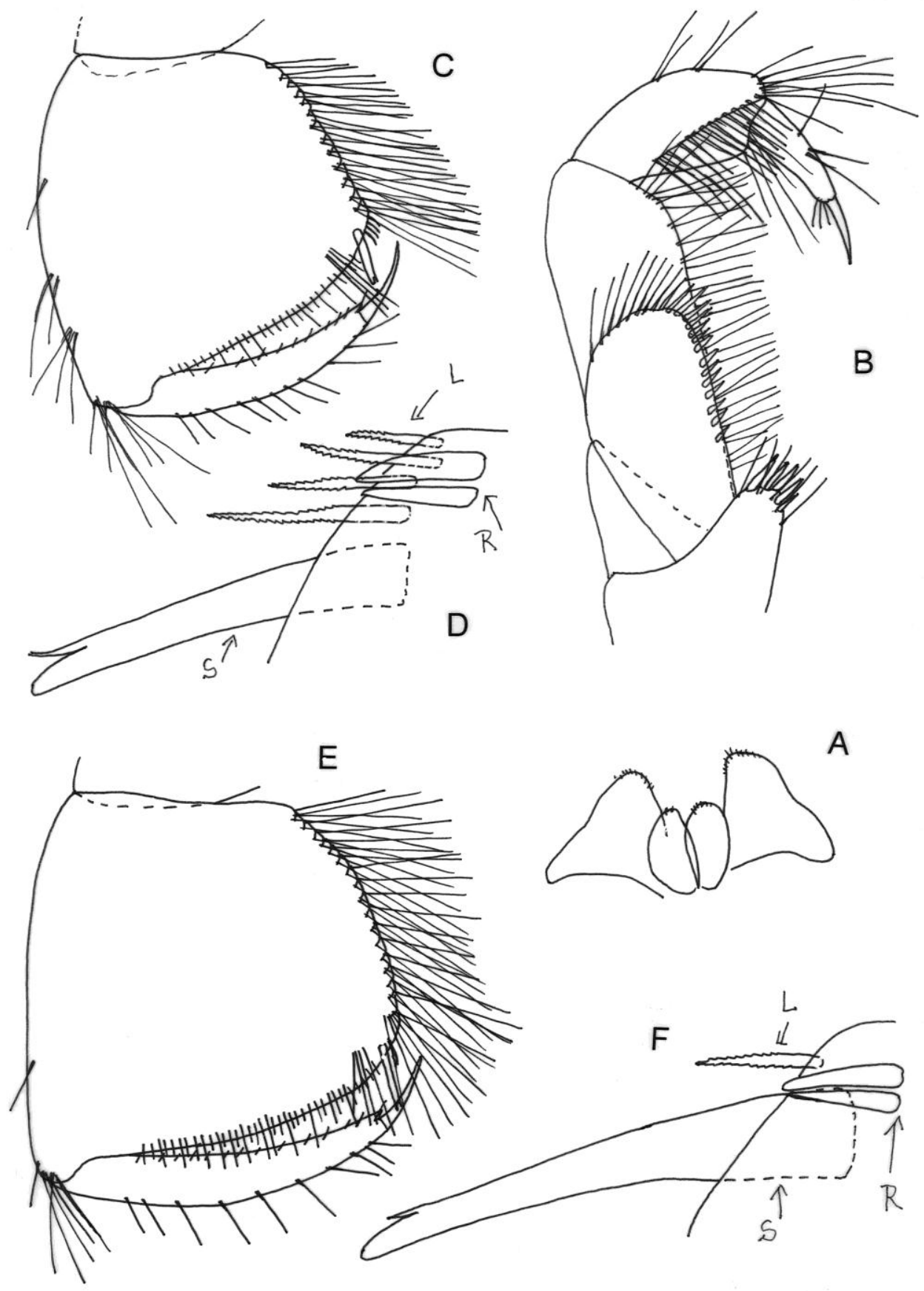

Fig. 2. Niphargus polymorphus Fišer, Trontelj \& Sket, 2006, Nikšić, Zavrh, female 19.6 $\mathrm{mm}$ : $\mathrm{A}=$ labium; $\mathrm{B}=$ maxilliped; $\mathrm{C}$ - gnathopod 1 propodus, outer face; $\mathrm{D}=$ distal corner of gnathopod 1 propodus, inner face; $\mathrm{E}=$ gnathopod 2 propodus, outer face; $\mathrm{F}=$ distal corner of gnathopod 2 propodus, inner face. 
Epimeral plates 1-3 distinctly pointed, epimeral plate 2 with 2 subventral spines, epimeral plate 3 with 3 subventral spines. Urosomal segment 1 on each dorsolateral side with 3 spines; urosomal segment 2 on each dorsolateral side with 4 spines; urosomal segment 3 naked. Urosomal segment 1 on each side with one short strong ventroposterior spine near basis of the uropod 1 peduncle.

Antenna 1 remarkably exceeding half of body (ratio: 165:195); peduncular articles 1-3 relatively slender, progressively shorter (ratio: 71:51:37), peduncular article 1 scarcely setose; peduncular articles 2-3 with several bunches of short setae each (fig. 1A); main flagellum consisting of 57 articles (most of them with 1-2 short aesthetascs each) (fig. 1B).

Antenna 2 relatively slender, moderately setose (fig. 1C); peduncular articles 4 and 5 nearly equally long; peduncular article 4 at dorsal margin with single spines and 3-4 bunches of short setae, at ventral margin with 4 bunches of setae longer than diameter of articles themselves; article 5 at dorsal margin with 5-6 bunches of setae, at ventral margin 4-5 bunches of setae remarkably longer than diameter of articles themselves. Flagellum relatively slender, longer than last peduncular article (ratio: 119:74), scarcely setose, consisting of 13-15 articles (fig. 1C). Antennal gland cone slightly exceeding distal margin of peduncular article 3 of antenna 2 (fig. 1C).

Labrum entire; labium broader than long, with entire subrounded inner and outer lobes (fig. 2A).

Mandible: palpus article 1 naked; article 2 along ventral margin with 24 setae (fig. 1E); palpus article 3 falciform, slightly longer than article 2 (ratio: 68:58), with 6 distal E-setae and 30-32 marginal D-setae; on outer face appears one row of 9 A-setae (fig. 1F), on inner face are attached 6-7 bunches of B-setae (4-2-3-4-4-4) (1E).

Maxilla 1: inner plate with 5 setae, outer plate with 7 spines [6 spines with 1 lateral tooth, 1 spine with 2-3 lateral teeth; palpus 2articulated, second article not reaching tip of outer plate spines, bearing 10 setae (fig. 1D).

Maxilliped: inner plate short, with 5 smooth distal spines intermixed with single setae (fig. 2B); outer plate reaching nearly half of palpus article 2; palpus article 3 along outer margin with 1-2 median and 1 distal bunch of setae; article 4 (dactylus) at outer margin with 2 bunches of median setae, at inner margin with distoventral bunch of 3 setae near basis of the nail, nail short (fig. 2B).

Coxae 1-4 longer than broad, with row of longer setae along ventral margin. Coxa 1 longer than broad (ratio: 75:50), with subrounded and hardly produced ventroanterior corner, bearing 16 ventral marginal setae (fig. 3A). Coxa 4 much longer than broad (ratio: 93:64), with marked ventroposterior lobe (fig. 3B). 


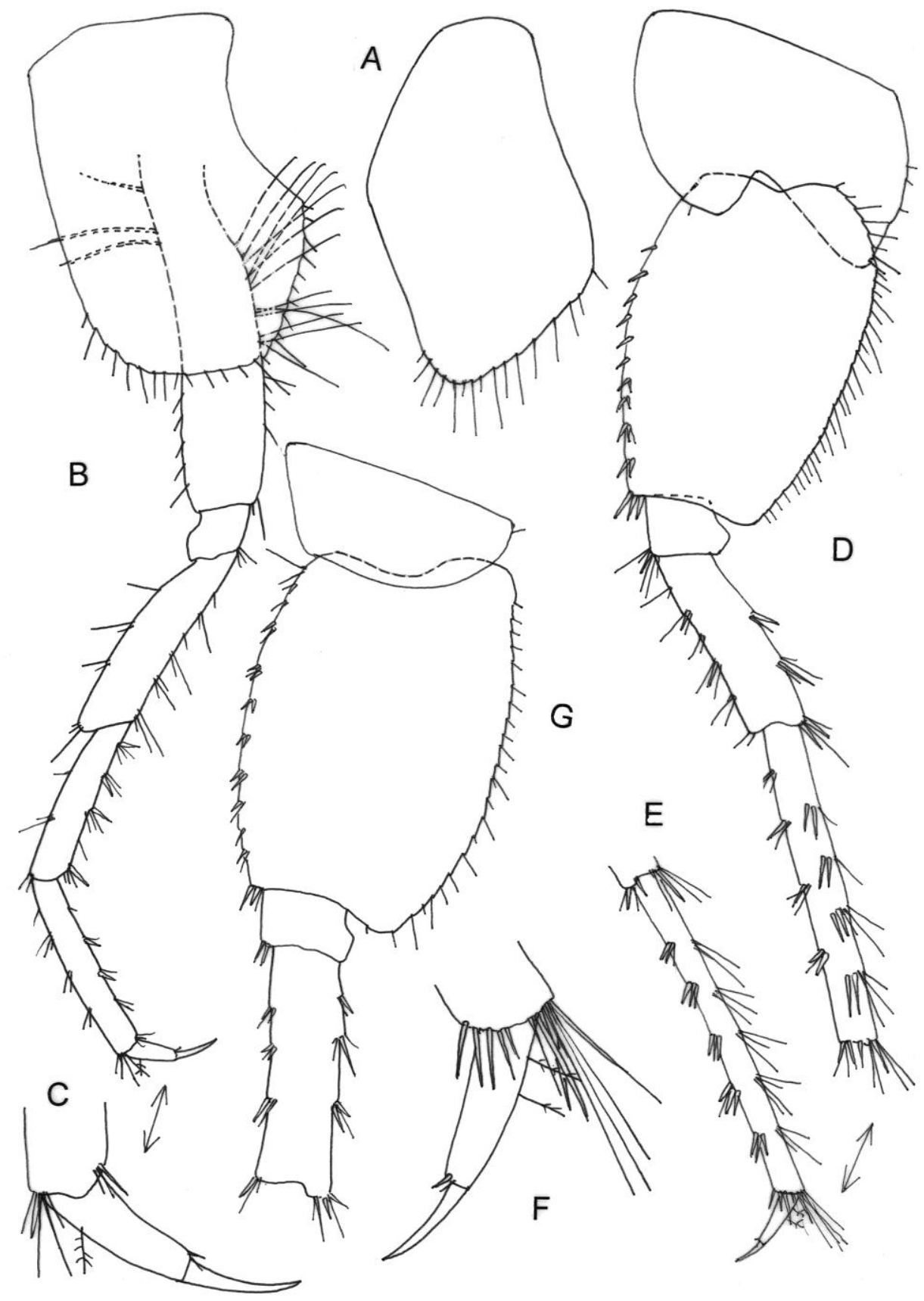

Fig. 3. Niphargus polymorphus Fišer, Trontelj \& Sket, 2006, Nikšić, Zavrh, female 19.6 $\mathrm{mm}: \mathrm{A}=$ coxa $1 ; \mathrm{B}-\mathrm{C}=$ pereopod $4 ; \mathrm{D}-\mathrm{F}=$ pereopod $5 ; \mathrm{G}=$ pereopod 7. 
Coxae 5-6 broader than long, scarcely setose, with posterior subangular lobe larger than anterior more subrounded lobe (fig. 3D). Coxa 7 shallow, convex (fig. $3 \mathrm{G}$ ).

Gnathopods 1-2 relatively small. Gnathopod 1: article 5 shorter than article 6 (propodus), along anterior margin with distal bunch of setae only. Propodus trapezoid, longer than broad (ratio: 92:85), along posterior margin with 13 transverse groups of setae (fig. 2C). Palm slightly convex, inclined almost $2 / 5$ of propodus-length, defined on outer plate by 1 corner $\mathrm{S}$-spine accompanied laterally by 4 slender L-spines and one bunch of 4 facial setae (fig. 2C, D), on inner face by 2 slender sub-corner R-spines (fig. 2D). Dactylus reaching posterior margin of propodus, along outer margin with row of 11 single setae (fig. 2 C).

Gnathopod 2 slightly larger than gnathopod 1, article 5 shorter than article 6 (propodus), along anterior margin with distal bunch of setae only. Propodus trapezoid, hardly longer than broad (ratio: 100: 96), along posterior margin with 17 transverse groups of setae. Palm slightly convex, inclined almost half of propodus-length, defined on outer face by 1 corner S-spine accompanied laterally by 1 slender L-spine and 3-4 facial M-setae (fig. 2E), on inner face by 2 sub-corner R-spines (fig. 2F). Dactylus reaching posterior margin of propodus, along outer margin with row of 10 single setae (fig. 2E).

Pereopods 3-4 relatively slender, scarcely setose, similar to each other. Pereopod 4: articles 4-6 of unequal length (ratio: 52:45:51), along both margins with bunches of relatively short setae, setae along posterior margin of article 4 are rather longer (fig. 3B). Dactylus moderately slender, much shorter than article 6 (ratio: 24:53), along inner margin with one spine-like seta near basis of the nail, along outer margin with one median plumose seta (fig. 3C); nail slightly shorter than peduncle (ratio: 38:50).

Pereopod 5: article 2 ovoid, longer than broad (ratio: 91: 61), along anterior convex margin with 10-11 pairs of very short spines and without ventroanterior protrusion (fig. 3D), along posterior margin with 34 setae of unequal length, ventroposterior lobe poorly developed (fig. 3D). Articles 4-6 of unequal length (ratio: 50:86:92), articles 4-5 along both margins with bunches of short spines mixed with single setae longer than the spines; article 6 along anterior margin with 6 bunches of spines, along posterior margin with 6-7 bunches of simple setae (fig. 3E). Article 2 is nearly as long as article 6. Dactylus much shorter than article 6 (ratio: 23:92), along inner margin with one spine-like seta and 1 lateral seta near basis of the nail, along outer margin with 2 median plumose setae; nail shorter than pedestal (ratio: 28:43) (fig. 3F).

Pereopod 6 rather similar to pereopod 5 but distinctly longer, dactylus like that of pereopod 5, along inner margin with one strong seta, along outer margin with 2 median plumose setae. 
Pereopod 7: article 2 longer than broad (ratio: 111:66), along anterior convex margin provided with 10-12 bunches of short spines, distoanterior protrusion missing (fig. 3G), posterior margin convex, bearing 23 unequally long setae, ventroposterior lobe shallow. Article 4 shorter than article 2 (ratio: 62:111), along both margins appear 4 bunches of short spines intermixed with short setae (fig. 3G); articles 5-7 missing.

Pleopods 1-3 with 3 retinacula each. Peduncle of pleopod 1 at distoanterior margin with 5 short setae; peduncle of pleopod 2 along anterior margin with 2 distal setae; peduncle of pleopod 3 along posterior margin with 2 strong distal setae.

Uropod 1: peduncle with dorsoexternal and dorsointernal row of strong spines; rami of equal length, bearing 4-5 groups of lateral spines mixed with single plumose setae.

Uropod 2: inner ramus hardly longer than outer one, at dorsal margin with 3 bunches of strong spines accompanied by plumose setae; outer ramus slightly recurved, with 3 bunches of strong spines and single plumose setae.

Uropod 3 stout, peduncle with distal spines (fig. 1G); inner ramus short, scale-like, with 2 distal spines; outer ramus first article longer than peduncle (ratio: 43:103), along outer margin with 5 bunches of short spines, at inner margin with 7 bunches of spines mixed with pairs of long plumose setae; second article shorter than diameter of first article, bearing 4 distolateral short simple setae (fig. 1G).

Telson longer than broad (ratio: 86:74), slightly gapping, each lobe with 6 slender spines and 0-1 seta; a pair of plumose setae is attached in the middle of each lobe (fig. $1 \mathrm{H}$ ).

Coxal gills on gnathopod 2 and pereopods 3-4 large, reaching ventral tip of corresponding article 2, coxal gills on pereopods 5-6 are ovoid, much shorter.

Oostegites large, with long marginal setae.

MALES unknown.

TYPE LOCALITY: Bileća, Bosnia and Herzegovina.

LOCALITIES CITED: Bosnia and Herzegovina: Bileća (Fišer et al., 2006).

Montenegro: Nikšić, Zavrh, well (new).

DISCUSSION. $N$. polymorphus differs remarkably from most of known species of the Orniphargus group of taxa (Subgenus Orniphargus S. Karaman, 1950) by combination various characters (number of retinacula, presence of $2 \mathrm{R}$-spines on propodus of gnathopods 1-2, shape of pereopods, uropod 3 , etc.). 
Morphologically, the most closed species to $N$. polymorphus is $N$. carcerarius G. Karaman, 1988, known from the spring/cave in Đurđevića Tara (N. Montenegro) (pereopods, elevated number of $\mathrm{R}$-spines on gnathopods 1-2, slightly gapping telson, produced ventroanterior corner of coxa 1 bearing a row of longer setae, outer margin of dactylus in pereopods 5-7 with elevated number of plumose setae; and spine-like seta at inner margin near basis of the nail, etc.).

But $N$. carcerarius differs from $N$. polymorphus by absence of dorsolateral spines on metasomal segments $1-3$, by presence of 2 retinacula only, different number of spines on lobes of telson, smaller body-size.

All known specimens of $N$. carcerarius (females) were not quite adult and the adult males of $N$. carcerarius and $N$. polymorphus are unknown. The detailed differences between both species can be established after finding of new material from cave in Đurđevića Tara and the males from Bileća.

\section{NIPHARGUS POIANOI SALERNIANUS sSp. $\mathrm{n}$.}

Figures 4-9

Niphargus patrizii (part.) G. Karaman, 1993: 232 (Festolaro Cave).

MATERIAL EXAMINED: ITALY (Campagna): -S. Angelo a Fasanella (Salerno), Monti Alburni, cave/spring of Auso River, 18.9.1994, 4 spec. (leg. S. Inguscio) holotype and paratypes);

S-6331a= Grotta del Festolaro Cave, Valle dell Angelo (Salerno, Italy), 26.6.1973, 1 spec. (leg. S. Cantilena \& D. Capolongo).

DESCRIPTION: FEMALE $11.2 \mathrm{~mm}$ (holotype) bearing oostegites with short setae (S. Angelo a Fesanella): Head with poorly convex dorsal surface (in lateral projection), lateral cephalic lobes short and subrounded (fig. 4A), ventroanterior sinus developed. Mesosomal segments smooth. Metasomal segments 1-3 with 4-5 dorsoposterior setae each (fig. 6E). Urosomal segment 1 on each dorsolateral side with 1 spine, urosomal segment 2 on each dorsolateral side with 4 spines (fig. 4E); urosomal segment 3 smooth. Urosomal segment 1 on each ventroposterior corner with 1 strong ventroposterior spine near basis of the uropod 1 peduncle (fig. 4E).

Epimeral plates 1-2 slightly acute, epimeral plate 1 with almost straight or slightly inclined posterior margin bearing 4-5 short setae (fig. 6E); epimeral plate 3 pointed with slightly concave posterior margin bearing 8 short setae. Epimeral plate 2 with one subventral spine, epimeral plate 3 with 3 subventral spines (fig. $6 \mathrm{E})$. 

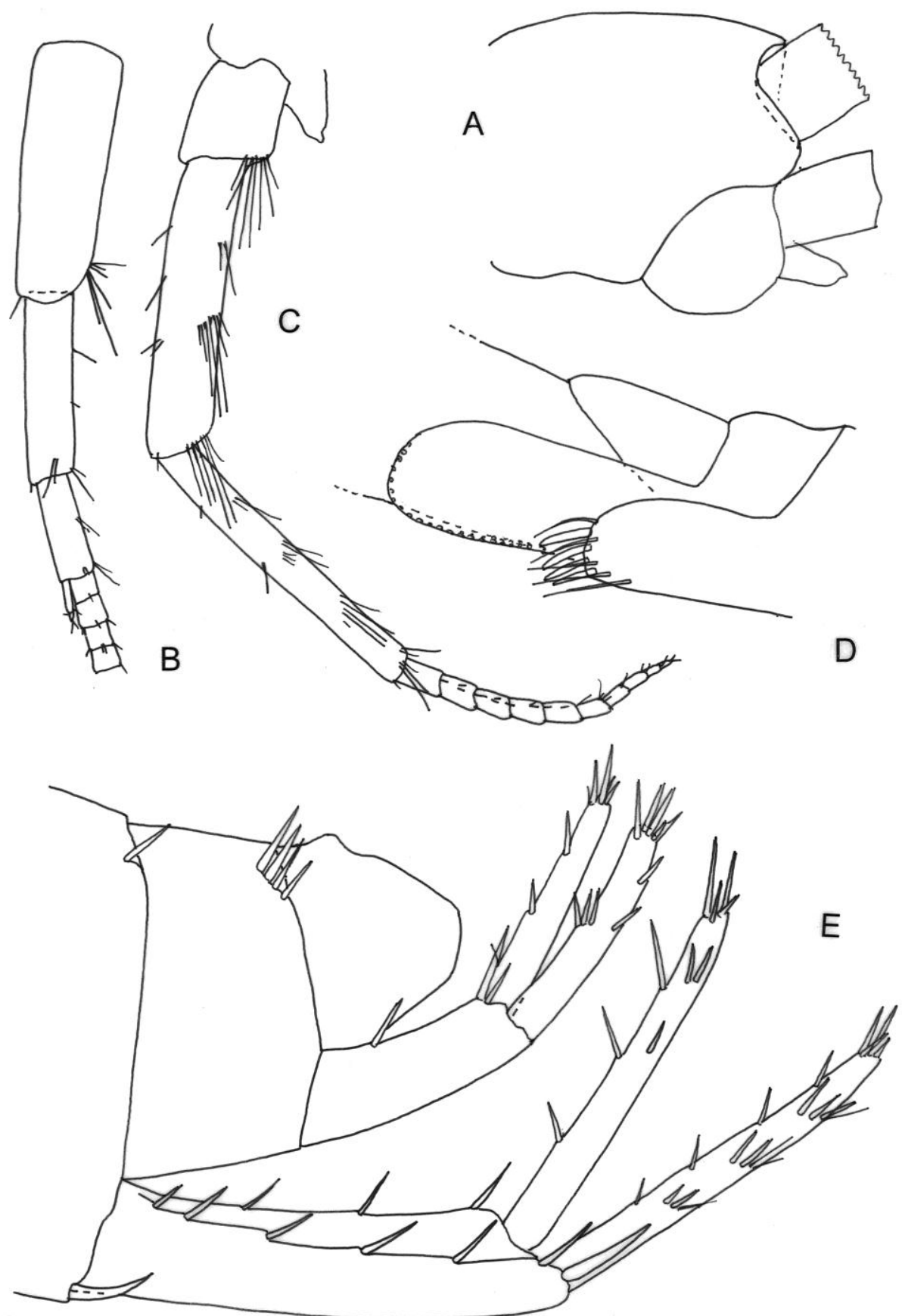

Fig. 4. Niphargus poianoi salernianus, ssp. n. ssp., Angelo a Fasanella, Salerno, Italy, female $11.2 \mathrm{~mm}: \mathrm{A}=$ head; $\mathrm{B}=$ antenna 1 , proximal part; $\mathrm{C}=$ antenna $2 ; \mathrm{D}=$ maxilliped, inner plate; $\mathrm{E}=$ urosome with uropods $1-2$. 
Antenna 1 reaching nearly half of body-length; peduncular articles 1-3 scarcely setose, progressively shorter (ratio: 67:49:26); main flagellum with 34 articles bearing 1-2 short aesthetascs each. Accessory flagellum short, 2articulated (fig. 4B).

Antenna 2: peduncular article 3 short, with ventrodistal bunch of setae (the longest setae nearly reaching the width of article itself); peduncular article 4 hardly shorter than article 5 (ratio: 78:84), bearing 3 bunches of longer setae along ventral margin (fig. 4C); article 5 along ventral margin with 4 bunches of setae; setae are much shorter along dorsal margin of peduncular articles 4 and 5. Flagellum relatively slender, slightly shorter than last peduncular article (ratio: 84:75), composed of 10 articles scarcely setose, setae are short (fig. 4C). Antennal gland cone short (fig. 4C).

Labrum broader than long, convex distally. Labium with well-developed inner lobes, outer lobes entire.

Mandible molar triturative, like that in $N$. poianoi; palpus article 1 smooth, palpus article 2 with 20 setae (fig. $8 \mathrm{~B}$ ), palpus article 3 longer than 2 (ratio: 83:70), with 2 groups (7+1) of A-setae (fig. 8C), 4 groups of B-setae (3-4-2-2), 32 D-setae and 7 E-setae (fig. 8B).

Maxilla 1: inner plate with 4 setae, outer plate with 7 spines ( 6 spines with 1 lateral tooth, 1 with 2 teeth (right mandible) (fig. 8A), or with 5 spines bearing 1 tooth, 1 spine with 2 teeth, 1 spine with 3 teeth (left mandible); palpus short, 2articulated, not exceeding tip of spines of outer plate and bearing 7-8 setae (fig. $8 \mathrm{~A})$.

Maxilla 2: both plates with marginal setae only.

Maxilliped: inner plate short, not reaching outer tip of first palpus article, and bearing 4 distal spines (fig. 4D); outer plate reaching nearly half of second palpus article, spines entire, palpus well developed.

Coxae 1-4 longer than broad, with straight anterior margin and bearing a row of several short setae. Coxa 1 nearly as long as broad, with subangular ventroanterior corner (fig. 5A). Coxa 2 longer than broad (ratio: 72: 45) and broadly subrounded ventroposterior corner (fig. 5C). Coxa 3 longer than broad (ratio: 85:57), with broadly subrounded ventroposterior corner (fig. 6A). Coxa 4 slightly longer than broad (ratio: 85:61), with well marked subangular ventroposterior corner (fig. 6D).

Coxae 5-7 progressively smaller. Coxa 5 is shorter than 4 , broader than long (ratio: 70:48) with broad subrounded anterior lobe and straight shallow posterior part (fig. 7A). Coxa 6 bilobed, much broader than long (ratio: 57:39) (fig. 7C). Coxa 7 entire, broader than long (ratio: 60:30), convex ventrally (fig. $7 \mathrm{E})$.

Propodus of gnathopods 1-2 not larger than corresponding coxae. Gnathopod 1 smaller than gnathopod 2, with article 2 stout, bearing many long setae along anterior and posterior margin; article 3 at posterior margin with one bunch of setae (fig. 5A ); article 5 shorter than propodus (ratio: 40:54), along anterior margin with distal bunch of setae. 


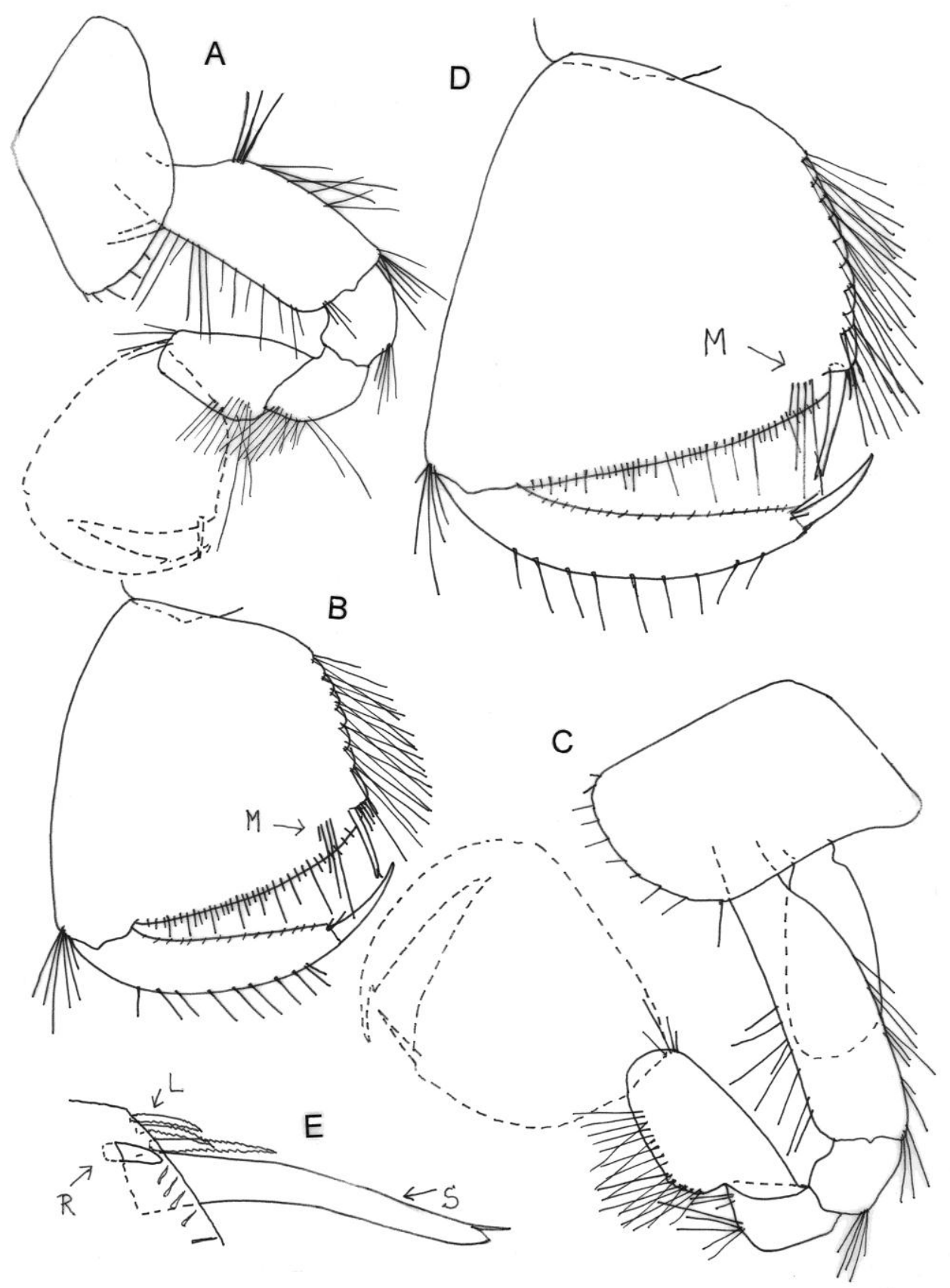

Fig. 5. Niphargus poianoi salernianus, ssp. n. ssp., Angelo a Fasanella, Salerno, Italy, female $11.2 \mathrm{~mm}: \mathrm{A}-\mathrm{B}=$ gnathopod 1 , outer face; $\mathrm{C}-\mathrm{D}=$ gnathopod 2, outer face; $\mathrm{E}=$ distal corner of gnathopod 2 propodus, inner face. 
Propodus trapezoid, slightly longer than broad (ratio: 81:93), along posterior margin with 7 transverse rows of setae (fig. 5B). Palm slightly convex, inclined nearly to the half of propodus-length, defined on outer face by one strong corner S-spine accompanied laterally by 4 slender L-spines and 4 facial $\mathrm{M}$-setae, on inner face by one short subcorner R-spine; dactylus reaching posterior margin of dactylus, along outer margin with 8 single setae and one pair of setae (fig. 5B).

Gnathopod 2: article 2 along both margins with long setae; article 3 with 1 distoposterior group of setae (fig. 5C); article 5 shorter than 6 (ratio: 51:66). Propodus trapezoid, nearly as long as broad, with 9 transverse groups of setae along posterior margin (fig. 5D. Palm slightly convex, inclined nearly half of propodus-length, defined on outer face by 1 corner S-spine accompanied laterally by $3 \mathrm{~L}$-spines and 4 facial M-setae (fig. 5D, E), on inner face by one short Rspine (fig. 5E). Dactylus reaching posterior margin of propodus, along outer margin with row of 9 single setae (fig. 5D).

Pereopods 3-4 slightly elongated, provided mainly with setae along anterior and posterior margin (fig. 6A. D). Pereopod 3: articles 4-6 of unequal length (ratio: 67:42:56) (fig. 6A). Dactylus slender, much shorter than article 6 (ratio: 32:56), along inner margin with one small seta near basis of the nail (fig. $6 \mathrm{~B})$, along outer margin with one median plumose seta; nail shorter than pedestal (ratio: 40:53).

Pereopod 4 is similar to pereopod 3 (fig. 6D), articles 4-6 of unequal length (ratio: 60:44:50). Dactylus like that of pereopod 3 (fig. 6D), along inner margin with one spine-like seta near basis of the nail, at outer margin with one median plumose seta.

Pereopods 5-7 relatively slender and elongated, progressively longer towards pereopod 7. Pereopod 5: article 2 almost twice as long as broad (ratio: 99:58), anterior margin remarkably convex but not produced ventrally, and bearing 9 single spines (fig. 7A), posterior margin weakly sinusoid, bearing 15 short setae, ventroposterior part not fully lobed. Articles 4-6 of unequal length (ratio: 60:84:90), covered mainly along both margins with bunches of short spines. Article 6 is rather shorter than article 2 (ratio: 90:100) (fig. 7B). Dactylus much shorter than article 6 (ratio: 25: 90), along inner margin with one small seta near basis of the nail, along outer margin with one median plumose seta; nail is shorter than pedestal (fig. 7B).

Pereopod 6: article 2 much longer than broad (ratio: 108:60), anterior margin not produced ventrally, slightly less convex than that of pereopod 5 , bearing 10 spines; posterior margin almost straight in the middle, bearing 13 setae or spine-like setae, ventroposterior dilatation is not fully lobed (fig. 7C). Articles 4-6 of unequal length (ratio: 80:115:137), along anterior and posterior margin with bunches of spines (fig. 7D); Article 6 is longer than article 2 (ratio: 137: 107). Dactylus is much shorter than article 6 (ratio: 36: 137), at inner margin with one short seta near basis of the nail, along outer margin with one median plumose seta; nail is shorter than pedestal (fig. 7D). 


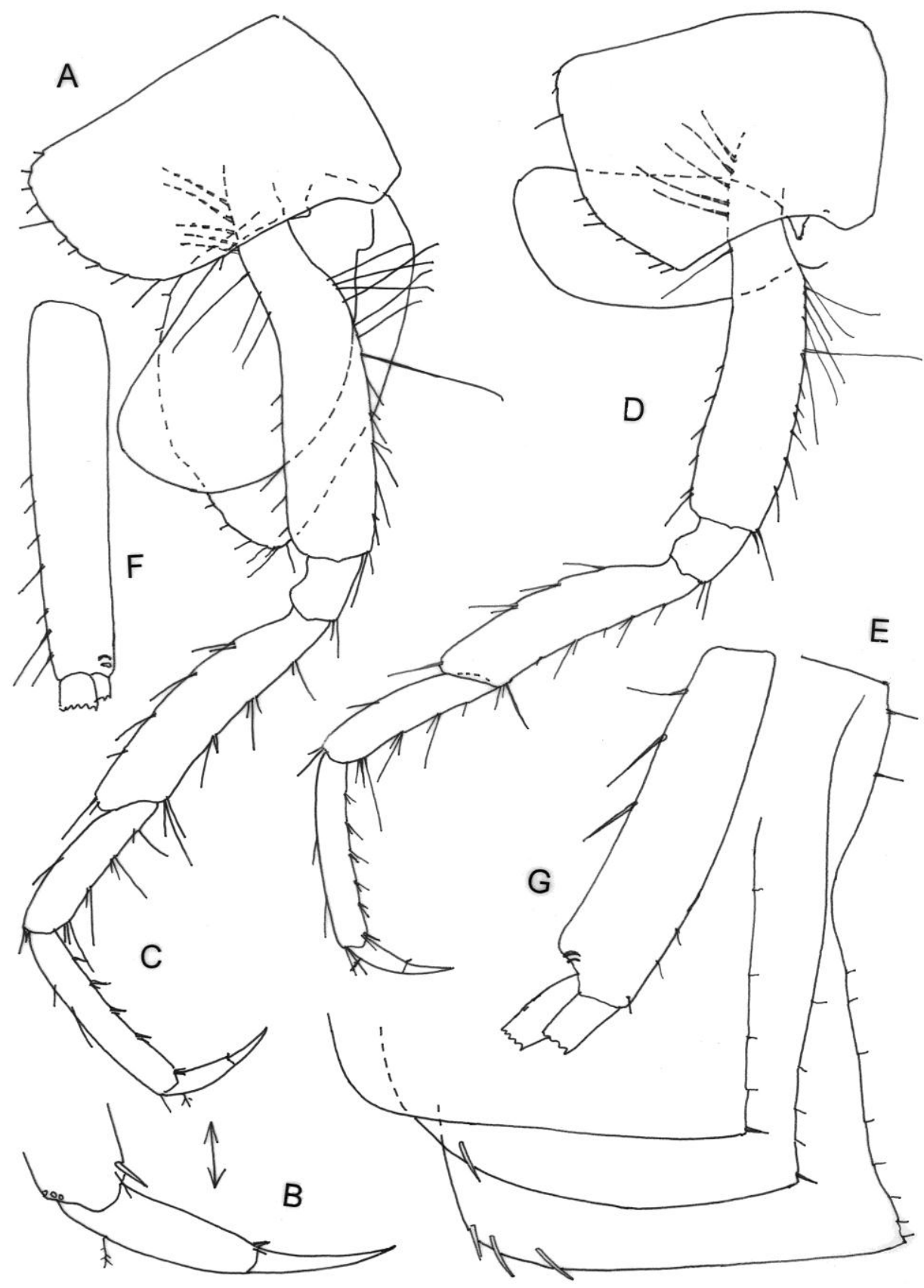

Fig. 6. Niphargus poianoi salernianus, ssp. n. ssp., Angelo a Fasanella, Salerno, Italy, female $11.2 \mathrm{~mm}: \mathrm{A}-\mathrm{C}=$ pereopod $3 ; \mathrm{D}=$ pereopod $4 ; \mathrm{E}=$ epimeral plates $1-3 ; \mathrm{F}=$ peduncle of pleopod $1 ; \mathrm{G}=$ peduncle of pleopod 3 . 
Pereopod 7: article 2 much longer than broad (ratio: 110: 61), anterior margin poorly convex, not produced ventrally, bearing 8 single spines; posterior margin slightly convex bearing 13 setae and spines (fig. 7E), ventroposterior lobe scarcely developed. Articles 4-6 of unequal length (ratio: 77:110:152), along anterior and posterior margin with bunches of strong spines (fig. 7F). Article 6 is much longer than article 2 (ratio: 152: 110). Dactylus is much shorter than article 6 (ratio: 37:152), along inner margin with one seta near basis of the nail, along outer margin with one median plumose seta (fig. $7 \mathrm{G}$ ); nail shorter than pedestal (ratio: 33:75).

Pleopods 1-3 with 2 retinacula each. Peduncle of pleopod 1 with row of 7 anterior short marginal setae (in lateral projection) (fig. 6F). Peduncle of pleopod 2 smooth; peduncle of pleopod 3 with 3 short anterior marginal setae and 3 strong posterior setae (fig. 6G).

Uropod 1: peduncle slightly longer than inner ramus (ratio: 125:120), with dorsointernal and dorsoexternal row of strong spines (fig. 4E); rami subequal, both are shorter than peduncle, bearing strong lateral and distal strong spines (fig. $4 \mathrm{E})$; along outer margin of outer ramus several simple setae are attached near the bunches of spines (fig. 4E).

Uropod 2: rami subequal, bearing strong short lateral and distal spines each (fig. 4E).

Uropod 3 relatively short, similar to other species of subgenus Orniphargus. Peduncle short, less than twice as long as broad, with bunches of strong distal spines (fig. 8E). Inner ramus shorter than peduncle, scale-like, bearing 2 distal spines and one plumose seta (fig. 8E). Outer ramus 2-articulated: first article strong, along both margins with 6 bunches of strong spines; single long plumose setae are attached near the bunches of spines along outer margin of outer ramus. Second article of outer ramus is very short, not exceeding the width of first article and bearing 2 short distal simple setae only (fig. 8E).

Telson nearly as long as broad, incised over $2 / 3$ of its length; each lobe with 3 distal spines, lateral and facial spines absent; a pair of short plumose setae appears near the middle of each lobe (fig. 8D).

Coxal gills appear on mesosomal segments 2-6, ovoid, not exceeding ventral tip of pereopods article 2 (figs. 5C; 6D; F; 7A, C).

Oostegites broad, with short marginal setae only (fig. 6C).

MALE: Unknown.

\section{VARIABILITY: The juvenile exp of $6.2 \mathrm{~mm}$ :}

Metasomal segments 1-3 with 4 dorsoposterior longer setae each. Urosomal segment 1 with 1 spine on each dorsolateral side; urosomal segment 2 with 2 spines on each dorsolateral side. Urosomal segment 1 on each lateral side with strong ventroposterior spine near basis of the uropod 1 peduncle, like that in female. 


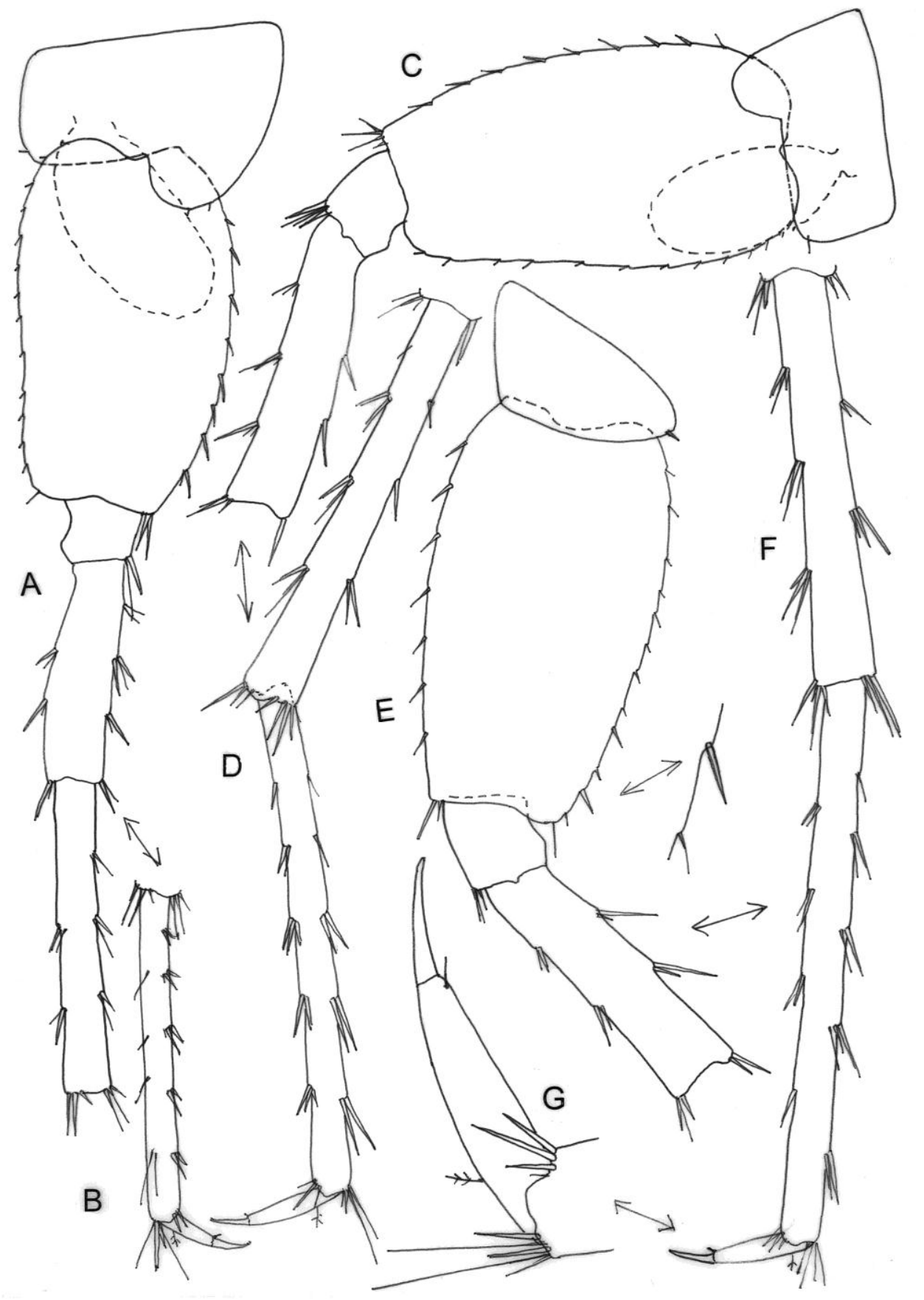

Fig. 7. Niphargus poianoi salernianus, ssp. n. ssp., Angelo a Fasanella, Salerno, Italy, female $11.2 \mathrm{~mm}$ : A-B= pereopod 5; C-D= pereopod 6; $\mathrm{E}-\mathrm{G}=$ pereopod 7. 


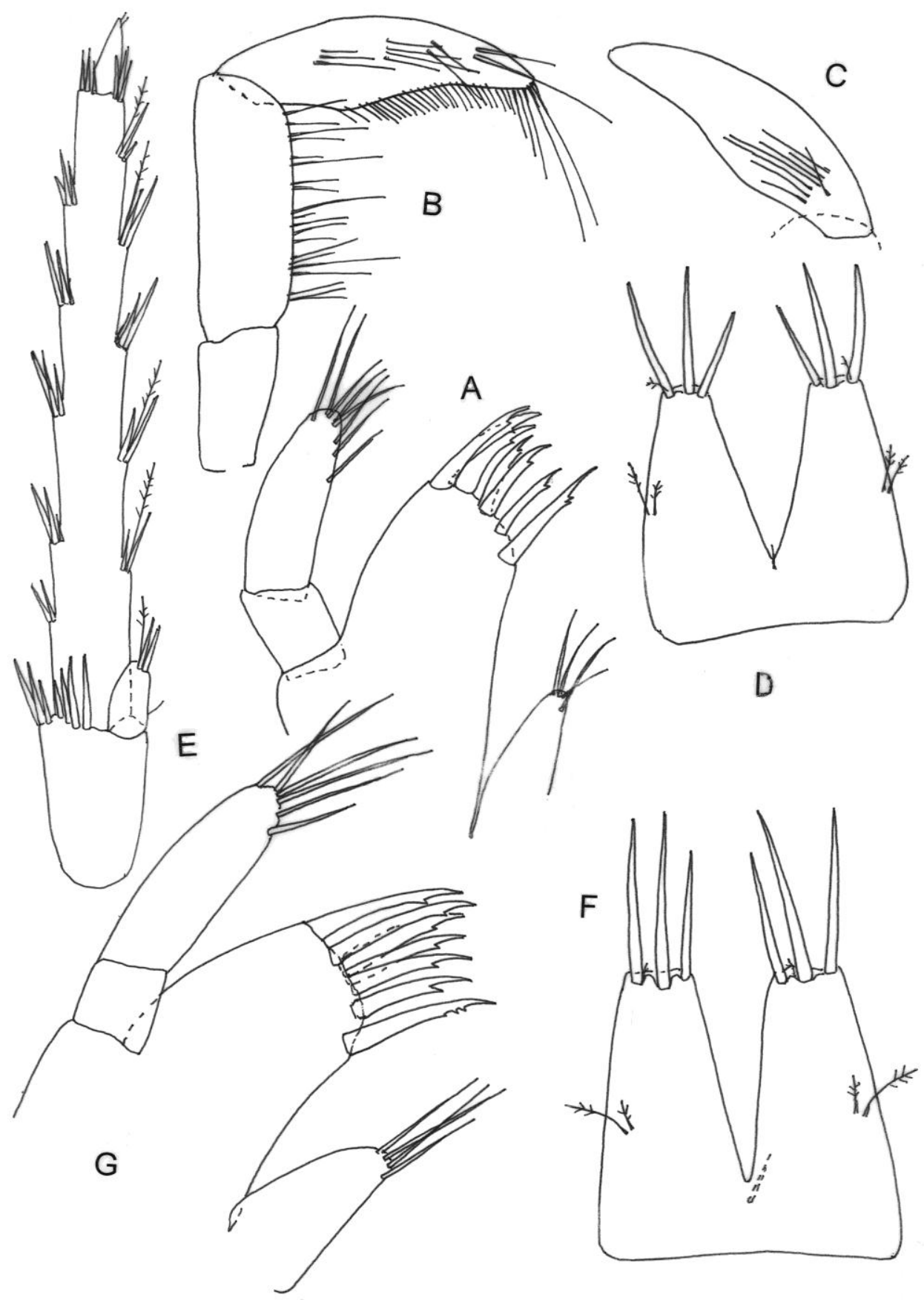

Fig. 8. Niphargus poianoi salernianus, ssp. n., S. Angelo a Fasanella, Salerno, Italy, female $11.2 \mathrm{~mm}$ : $\mathrm{A}=$ maxilla $1 ; \mathrm{B}=$ mandible palpus, inner face; $\mathrm{C}=$ distal article of mandible palpus, outer face; $\mathrm{D}=$ telson; $\mathrm{E}=\operatorname{uropod} 3$.

Grotta del Festolaro Cave, Salerno, Italy, female $9.5 \mathrm{~mm}$ : F= telson; G= maxilla 1. 


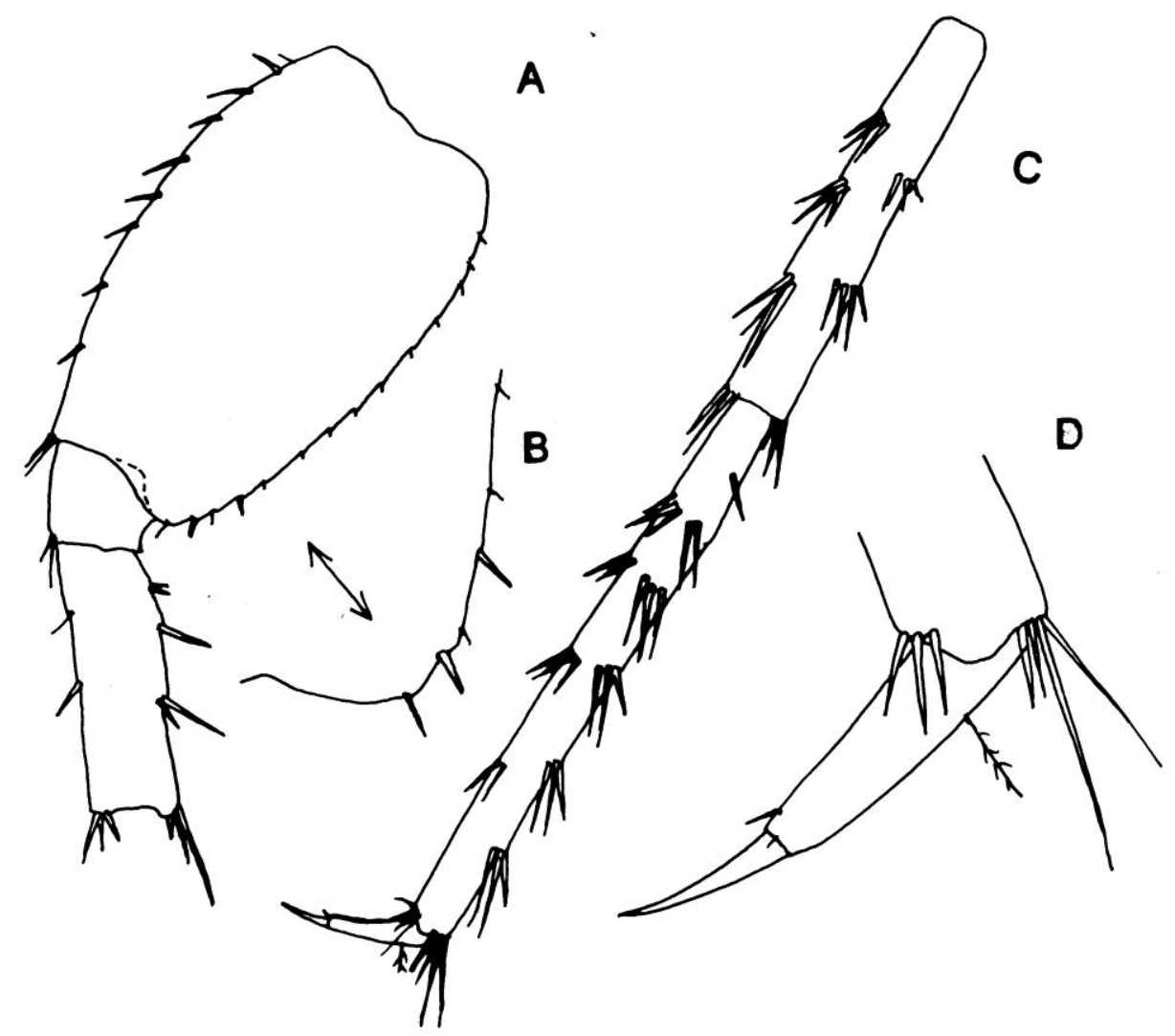

Fig. 9. Niphargus poianoi salernianus, ssp. n., Grotta del Festolaro Cave, Salerno, Italy, female $9.5 \mathrm{~mm}$ : A-C= pereopod 7; $\mathrm{D}=$ dactylus of pereopod 7 .

Antenna 1 exceeding half of body. Flagellum of antenna 2 as long as or slightly longer than last peduncular article, provided with 9-10 articles.

Inner plate of maxilla 1 with 2 setae; coxa 1 with subrounded ventroanterior corner, coxae 1-2 with subrounded lateral margins (not angular). Pereopods 5-7 like these in female; segment 2 of pereopods 6-7 narrowed, with straight posterior margin bearing setae intermixed with single spines. Dactylus of pereopods 3-7 slightly shorter.

Telson nearly as long as broad, tapering distally; each lobe with 3 distal and 1 outer marginal spine.

The two juv. spec. of $5.8 \mathrm{~mm}$ : telson with or without lateral spine; posterior margin of segment 2 in pereopod 7 provided with spines and setae. Coxa 1 with subangular ventroanterior corner.

Grotta del Festolaro Cave: The female of $9,5 \mathrm{~mm}$ with large oostegites agree mainly with that from S. Angelo. Antenna 1 almost reaching half of body- 
length, main flagellum consisting of 31 articles. Flagellum of antenna 2 is nearly as long as last peduncular article and consisting of 9 articles.

Metasomal segments 1-3 along dorsoposterior margin with 4 setae only. Urosomal segment 1 on each dorsolateral side with 1 spine, urosomal segment 2 on each dorsolateral side with 4 spines, urosomal segment 3 smooth.

Mouthparts like these of S. Angelo, inner plate of maxilla 1 with 4 setae, outer plate with 7 spines ( 6 spines with one lateral tooth, one spine with 3 lateral teeth (fig. 8G), palpus relatively short, with 6 distal setae.

Coxae 1-4 like these of S. Angelo or hardly less angular. Pereopods 3-7 mainly like these of S. Angelo.

Pereopod 7: posterior margin of article 2 slightly convex, bearing 14 short setae and slender spines, ventroposterior lobe is shallow (fig. 9A, B); article 6 is much longer than article 2 (ratio:124:95) (fig. 9A, C). Dactylus of pereopods 3-7 with seta at inner margin near the basis of the nail (fig. 9D).

Uropods 1-3 like these in S. Angelo. Telson nearly as long as broad, each lobe with 3 long distal spines only, facial and lateral spines absent (fig. 8F).

\section{REMARKS.}

The specimens from S. Angelo a Fasanella are very close to the species Niphargus patrizii Ruffo \& Vigna-Taglianti, 1968, known from Italian localities in province Lazio, described from Pastena cave $28 \mathrm{La} / \mathrm{FR}$ (Ausoni Mountains, Frosinone) and cited from Formale cave $39 \mathrm{La} / \mathrm{RM}$ (Lepini Mountains, Roma) (Ruffo \& Vigna Taglianti, 1968; G. Karaman, 1993).

G. Karaman (1993) mentioned it also for Grotta del Festolaro (Valle del' Angelo, Salerno). The recent analysis of Festolaro specimen suggested that specimens from Festolaro differ from N. patrizii by various characters.

The female from S. Angelo a Fasanella differs from female of Pastena Cave (N. patrizii) by more cutted anterior margin of coxae 1-4, by presence of 4 setae on maxilla 1 inner plate, by 4-5 short dorsoposterior marginal setae on metasomal segments 1-3 (spines are not present), by absence of lateral and facial spines on telson; urosomal segment 1 is with one spine on each dorsolateral side, propodus of gnathopods 1-2 is rather narrowed; article 2 of pereopod 7 with spines and setae inserted along posterior margin; pereopod 7 with article 6 remarkably longer than article 2 .

The female from S. Angelo a Fasanella is also very similar to N. poianoi G. Karaman, 1988b, described and known from springs in Poiano (Reggio Emilia, Italy) by presence of 4 dorsoposterior marginal setae on metasomal segments 1-3, by presence of single spines and setae along posterior margin of pereopods 6 and 7, by shape and pilosity of maxilla 1 and maxilliped, by number of dorsolateral spines on urosomal segments 1-3, by epimeral plates, pleopods 13 , etc. But $N$. poianoi differs from specimens from S. Angelo by subrounded and shorter coxae 1-4, by peduncular article 5 of antenna 2 shorter than article 4 , and flagellum distinctly longer that article 5; by presence of distinct spine at inner margin of dactylus of pereopods 5-7, by shorter article 2 of pereopods 5-7 
regarding corresponding basipodit; propodus of gnathopods 1-2 is slightly broader, telson with obtuse lobes bearing usually 4 distal and one facial spine; uropod 3 second article of outer ramus provided with lateral and distal simple setae].

At the present knowledge of $N$. poianoi, we cannot refer the specimens from Campagna (S. Angelo a Fasanella) to these of Reggio Emilia (Poiano springs) as identic, and we consider the specimens from S. Angelo as a distinct new subspecies, $N$. poianoi salernianus, ssp. n.

Niphargus poianoi poianoi is known from type locality only (Poiano springs, Reggio Emilia), and ssp. salernianus is known from the subteranean waters of Campagna. As the scarce number of localities of both taxa are known, the real relations between ssp. poianoi and ssp. salernianus is not satisfactorily clear, and the discovery of new localities of both taxa will resolve this problem.

HOLOTYPE (ovig. female $11.6 \mathrm{~mm}$ ) was preserved in the Museum of Natural History Verona, Italy.

DERIVATIO NOMINIS. The name "salernianus" arrives from the name of the region Salerno, where the species was collected.

ECOLOGY: in the spring, water $\mathrm{pH} 7.4$, temperature 12 degree (S. Angelo a Fasanella) and cave (Festolaro Cave).

\section{ACKNOWLDGEMENTS}

The species was studied in the Museum of Natural History in Verona. I am thankful to Prof. Dr Vladimir Pešic from the University of Podgorica for the collected specimen from Nikšić, used in this study. The realization of this paper was supported by the Montenegrin Academy of Sciences and Arts in Podgorica, Montenegro.

\section{REFERENCES}

Fišer, C., Trontelj, P. \& Sket, B. 2006. Phylogenetic analysis of the Niphargus orcinus species-aggregate (Crustacea: Amphipoda: Niphargidae) with description of new taxa.- Journal of Natural History, 2006; 40(41-43): 2265-2315.

Karaman G. 1969. XXVII. Beitrag zur Kenntnis der Amphipoden. Arten der Genera Echinogammarus Stebb. und Chaetogammarus Mart. an der jugoslawischer Adriaküste. Glasnik Republičkog zavoda za zaštitu prirode i Prirodnjačke zbirke u Titogradu. 2:59-84.

Karaman, G. 1970. XXV. Beitrag zur Kenntnis der Amphipoden. Kritische Bemerkungen über Echinogammarus acarinatus (S. Kar., 1931) und Echinogammarus stocki n. sp.- Poljoprivreda i šumarstvo, Titograd, 16 (1-2): 4566.

Karaman, G. 1988a. New Species of Family Niphargidae and new localities of some other subterranean Gammaridean Species from Yugoslavia (Contribution to the Knowledge of the Amphipoda 166). - Glasnik Republičkog. zavoda za zaštitu prirode- Prirodnjačkog muzeja Titograd, 19: 15-32. (1986). 
Karaman, G. 1988b. The new Species of the Genus Niphargus Schiödte (Gammaridea, fam. Niphargidae) from Italy and Yugoslavia (Contribution to the Knowledge of the Amphipoda 177). - Poljoprivreda i šumarstvo, Titograd, 34 ( 2-3): 11-31.

Karaman, G., 1993. Anfipodi delle acque dolci italiane. Fauna d'Italia, 31: 1-337. (Edizioni Calderini, Bologna).

Karaman, G. 2010. The current approach to the fauna of Amphipoda (Crustacea) in Bosnia and Herzegovina (Contribution to the Knowledge of the Amphipoda 250).Academy of Sciences and Arts of Bosnia and Herzegovina, danas“/Symposium Panel „Darwin Today“ Sarajevo, 24.11. 2009, Special Editions CXXIX, Department of Natural and Mathematical Sciences, Proceedings, Volume 17, $17-$ 28.

Karaman, G. 2012. Further investigations of the subterranean genus Niphargus Schiödte, 1849 (fam. Niphargidae) in Serbia. (Contribution to the Knowledge of the Amphipoda 264). Agriculture and Forestry, Podgorica, 58 (2): 45-64.

Karaman, S. 1950. Podrod Orniphargus u Jugoslaviji. I. Deo. (=Das Subgenus Orniphargus in Jugoslavien, Teil I.).- Srpska Akademija Nauka, Posebna Izdanja knj. 158, Odelenje Prirodno-matematičkih nauka, Beograd, 2: 119-136, 145-156, 160-167, figs. 1-61.

Ruffo, S. \& Vigna-Taglianti, A. 1968. Alcuni Niphargus delle acque soterranee dell Italia centro-meridionale e considerazioni sulla sistematica del gruppo orcinus (Amphipoda, Gammaridae). - Memorie del Museo civico di Storia Naturale, Verona, 16: 1-29. 